\title{
PENGARUH SELEKSI KARYAWAN DAN KOMUNIKASI TERHADAP PRESTASI KERJA KARYAWAN PADA PT. PELABUHAN INDONESIA I (PERSERO) MEDAN
}

\author{
Desielsa Panjaitan ${ }^{1}$, Sinar Ritonga ${ }^{2}$ \\ Universitas Katolik Santo Thomas Medan Jl. Setia Budi No. 479F, 20132, Indonesia \\ e-mail: desielsaunika@yahoo.com¹, sinarritonga58@gmail.com²
}

\begin{abstract}
PT. Pelabuhan Indonesia I (Persero) Medan is one of the State-Owned Enterprises (BUMN) in the form of company companies engaged in services, especially port services in Indonesia. Communication within the company is not good because there is still insufficient communication media in the company. As a result, employee performance in 2015-2017 experienced fluctuations. From the description, the research problem was formulated (1) how employee selection and communication on the work performance of PT. Indonesian Port I (Persero) Medan? (2) how much influence the selection of employees on employee performance at PT. Indonesian Port I (Persero) Medan? (3) how much influence communication has on employee work performance at PT. Indonesian Port I (Persero) Medan? (4) how much influence does employee selection and communication have on employee work performance at PT. Indonesian Port I (Persero) Medan. This study aims to determine the effect of employee selection and communication on employee performance at PT. Indonesian Port I (Persero) Medan. The benefit of research is to provide information material to the leadership regarding the influence of employee selection and communication on employee performance. The study population was all employees in the HR department at PT. Pelabuhan Indonesia I (Persero) Medan 123 people. The data needed is collected through interviews, questionnaires and documentation studies. The data analysis technique used is multiple linear regression equation, $F$ test and $t$ test.
\end{abstract}

Keywords: Employee Selection, Communication and Employee Performance.

\section{PENDAHULUAN}

Sumber daya manusia merupakan faktor produksi terpenting yang sangat berpengaruh terhadap pencapaian tujuan perusahaan. Karena faktor inilah yang melakukan penggunaan faktor-faktor produksi yang lain dalam perusahaan. Maka perusahaan perlu memberikan perhatian yang cukup pada tenaga kerjanya, agar tujuan yang ingin dicapai benar-benar terwujud sesuai dengan yang diharapkan.

Mengingat pentingnya peran aktif dari sumber daya manusia, maka perlu adanya pengelolaan sumber daya manusia dari pihak manajemen sehingga dapat memberikan hasil kerja yang optimal bagi perusahaan. Salah satu cara untuk mengoptimalkan hasil kerja karyawan yaitu penilaian prestasi kerja karyawan agar mendorong mereka untuk dapat melaksanakan tugas dan tanggung jawabnya dengan lebih baik.

Prestasi kerja karyawan merupakan hasil atau kinerja karyawan yang dinilai dari segi kualitas maupun kuantitas berdasarkan standar yang ditentukan oleh pihak organisasi (Budi Setiyawan dan Waridin, 2006:154). Prestasi kerja karyawan yang meningkat akan membawa kemajuan bagi perusahaan untuk dapat bertahan dalam suatu persaingan lingkungan bisnis yang tidak stabil. Oleh karena itu, upaya-upaya untuk meningkatkan prestasi kerja karyawan merupakan tantangan manajemen yang paling serius karena keberhasilan untuk mencapai tujuan dan kelangsungan hidup perusahaan tergantung pada kualitas kinerja sumber daya manusia yang ada didalamnya.

Salah satu aktivitas dalam pengelolaan SDM adalah seleksi dan komunikasi. Seleksi merupakan kegiatan perusahaan untuk memilih karyawan yang tepat untuk menduduki satu posisi tertentu yang ditawarkan oleh perusahaan. Sekaligus sebagai alat untuk mengeliminasi atau untuk tidak memilih karyawan lain yang diupayakan guna menduduki posisi yang 
ditawarkan. Lemahnya proses seleksi yang dilaksanakan dalam perusahaan akan mengakibatkan rendahnya komunikasi dan prestasi kerja karyawan dalam melaksanakan tujuan perusahaan.

Menurut Purwanto (2006:20), komunikasi merupakan suatu proses pertukaran informasi antar individu melalui suatu sistem yang lazim, baik dengan simbol-simbol, sinyalsinyal maupun perilaku tindakan. Kegagalan dalam organisasi banyak yang disebabkan oleh kurang tertatanya komunikasi yang dilakukan karyawan di organisasi tersebut. Komunikasi penting bagi organisasi karena komunikasi merupakan alat utama bagi anggota organisasi untuk dapat bekerja sama dalam melakukan aktivitas manajemen demi mencapai tujuan yang ditetapkan.

Prestasi kerja karyawan pada PT. Pelabuhan Indonesia I (Persero) Medan mengalami penurunan disebabkan oleh kurangnya komunikasi antara manajemen dengan karyawan. Hal ini dikarenakan saluran komunikasi organisasi yang digunakan bersifat formal, yang lebih mengarah pada komunikasi vertikal, yakni komunikasi yang hanya berjalan dari atasan ke bawahan dan hal ini dipengaruhi oleh sikap pimpinan. Komunikasi tersebut dapat berbentuk lisan maupun tulisan, seperti pemberian tugas baik dengan menggunakan percakapan secara langsung dengan manajemen ataupun dengan pemberian memo. Pemberian tugas tersebut kurang mendapat pengarahan yang jelas dan rinci. Hal tersebut menimbulkan kesulitan dalam mengerjakan tugas yang diberikan oleh pimpinan, karena komunikasi yang bersifat satu arah. Akibatnya, hasil yang diperoleh menjadi kurang maksimal dan sangat berpengaruh terhadap prestasi kerja karyawan dalam perusahaan.

Beberapa hasil penelitian terdahulu diantaranya adalah:

Penelitian terdahulu yang dilakukan oleh Purnama Sari (2006) dengan judul "Pengaruh Seleksi Karyawan Terhadap Prestasi Kerja Karyawan pada PT Mutualplus Global Resources Jakarta" menyimpulkan bahwa ada pengaruh positif dan signifikan antara seleksi karyawan terhadap prestasi kerja karyawan pada PT Mutualplus Global Resources Jakarta.

Penelitian terdahulu yang dilakukan oleh Febryandi (2016) dengan judul "Pengaruh Faktor Kepemimpinan dan Komunikasi Terhadap Prestasi Kerja Karyawan di PT. Kereta Api Indonesia (Persero) Sub. Divisi Regional III.2 Tanjung Karang Bandar lampung" menyimpulkan bahwa kepemimpinan dan-komunikasi secara parsial berpengaruh positif terhadap prestasi kerja karyawan pada PT. Kereta Api Indonesia (Persero) Sub. Divisi Regional III.2. Tanjung Karang Bandar Lampung.

PT. Pelabuhan Indonesia I (Persero) Medan bergerak dibidang jasa khususnya jasa kepelabuhan di Indonesia. Dengan jasa kepelabuhan yang diselenggarakan tersebut dapat menunjang terhadap kelancaran arus kapal, barang dan penumpang melalui pelabuhan. Perusahaan ini merupakan Badan Usaha Milik Negara (BUMN) yang berbentuk Persero. Perusahaan ini merupakan salah satu Badan usaha yang dikelola oleh negara atau daerah, dengan tujuan didirikannya adalah mencari keuntungan sahamnya dimiliki oleh pemerintah.

PT. Pelabuhan Indonesia I (Persero) Medan didirikan pada tahun 1960 yang berfungsi untuk memberikan layanan jasa kepelabuhan dan sebagai solusi pemerintah dalam pengelola pelabuhan umum di Indonesia. Perusahaan ini merupakan salah satu perusahaan kepelabuhan yang terbesar di Indonesia. Walaupun telah menjadi perusahaan yang besar dan berkembang tentu saja masih banyak hambatan yang dialami perusahaan.

Proses seleksi yang dilakukan oleh PT. Pelabuhan Indonesia I (Persero) Medan telah menggunakan metode terbuka. Dimana metode ini tidak hanya diinformasikan kepada para karyawan atau orang-orang tertentu saja. Tidak ada diskriminasi berdasarkan suku, agama, ras, golongan dan gender dalam proses seleksi. Proses seleksi dijalankan secara terbuka dengan melibatkan pihak ketiga. Dalam proses seleksi mengadakan test kepada calon karyawan yaitu test akademik, test psikologis, dan test kesehatan. Dimana hasil test tersebut sangat berpengaruh terhadap pengambilan keputusan apakah karyawan tersebut diterima atau ditolak. Tetapi proses seleksi pada PT. Pelabuhan Indonesia I (Persero) Medan tidak 
hanya didasarkan kepada perkiraan jumlah karyawan yang dibutuhkan dan pengalaman kerja saja.

\section{TINJAUAN PUSTAKA}

\section{A. Fungsi-Fungsi Manajemen Sumber Daya Manusia}

Dalam teorinya Rivai (2011:13) mengemukakan bahwa, fungsi-fungsi manajemen sumber daya manusia terdiri dari:

1. Fungsi Manajerial

a. Perencanaan (planning), yaitu kegiatan memperkirakan atau menggambarkan keadaan tenaga kerja agar sesuai dengan kebutuhan organisasi secara efektif dan efisien, dalam membantu terwujudnya tujuan organisasi. Perencanaan merupakan tahap awal dari pelaksanaan berbagai aktivitas perusahaan.

b. Pengorganisasian (organizing), yaitu kegiatan untuk mengatur karyawan dengan menetapkan pembagian kerja, hubungan kerja, delegasi wewenang, integrasi dan koordinasi dalam bentuk bagan organisasi.

c. Pengarahan (actuating), yaitu kegiatan memberi petunjuk kepada karyawan agar mau kerjasama dan bekerja seara efisien dalam membantu tercapainya tujuan organisasi.

d. Pengendalian (controlling), yaitu kegiatan mengendalikan karyawan agar mentaati peraturan organisasi dan bekerja sesuai dengan rencana. Bila terjadi penyimpangan atau kesalahan diadakan tindakan perbaikan.

2. Fungsi Operasional

a. Pengadaan, yaitu proses penarikan, seleksi, pendapatan, orientasi dan induksi untuk mendapatkan karyawan yang dibutuhkan organisasi.

b. Pengembangan, yaitu proses peningkatan keterampilan teknis, teoritis, konseptual, dan moral pegawai melalui pendidikan dan pelatihan.

c. Kompensasi, yaitu pemberian balas jasa langsung (direct) dan tidak langsung (indirect) berupa uang atau barang kepada karyawan sebagai imbalan jasa yang diberikan kepada organisasi.

d. Pengintegrasian, yaitu kegiatan untuk mempersatukan kepentingan organisasi dan kebutuhan karyawan, agar tercipta kerja sama yang serasi dan saling menguntungkan.

e. Pemeliharaan, yaitu kegiatan untuk memelihara atau meningkatkan kondisi fisik, mental dan loyalitas karyawan, agar mereka tetap mau bekerja sama sampai pensiun.

f. PHK (Pemutusan Hubungan Kerja), yaitu putusnya hubungan kerja seseorang karyawan dari suatu organisasi yang disebabkan oleh keingingan karyawan, keinginan perusahaan, berakhirnya kontrak kerja dan sebagainya.

Diantara fungsi-fungsi manajemen sumber daya manusia diatas, saling mempengaruhi satu sama lain. Apabila terdapat ketimpangan dalam salah satu fungsi, akan mempengaruhi fungsi yang lain. Tingkat efektivitas dan fungsi-fungsi manajemen sumber daya manusia tersebut, ditentukan oleh profesionalisme sumber daya manusia yang ada dalam perusahaan.

\section{B. Perencanaan Sumber Daya Manusia}

Perencanaan sumber daya manusia adalah suatu proses sistematis yang digunakan untuk memprediksi permintaan dan penyediaan SDM dimasa mendatang. Peran manajemen sumber daya manusia dalam mencapai misi organisasi adalah proses rekrutmen, seleksi, dan pelatihan guna mendapatkan tenaga kerja yang terampil dan memiliki keahlian sesuai dengan kebutuhan untuk mencapai tujuan organisasi. Jika perencanaan sumber daya manusia dilakukan dengan baik, akan diperoleh keuntungan-keuntungan sebagai berikut:

1. Manajemen puncak memiliki visi yang lebih baik terhadap aspek-aspek sumber daya manusia atau terhadap keputusan bisnis.

2. Manajemen dapat menempatkan "right man on the right place" dengan tepat sesuai dengan kebutuhan organisasi. 
3. Menambah sistem informasi menjadi lebih baik untuk mengetahui pengetahuan tentang profil karyawan, pekerjaan, keahlian, kemampuan, kompensasi yang adil dan layak, serta dapat memprediksi kebutuhan jumlah tenaga kerja saat ini dan yang akan datang.

Elemen-elemen perencanaan sumber daya manusia, antara lain:

1. Tujuan. Setiap organisasi sewajarnya mempunyai tujuan dan sasaran bagaimana beroperasi. Demikian pula dengan aktivitas perencanaan sumber daya manusia memiliki tujuan yang berdasarkan pribadi/individu sekaligus organisasi. Tujuan ini harus memuat daya yang representatif untuk kepentingan jangka panjang organisasi.

2. Perencanaan organisasi. Perencanaan ditujukan untuk mencapai tujuan organisasi. Perencanaan harus mendukung fungsi-fungsi yang lain, seperti pengorganisasian, susunan kepegawain, kepemimpinan, dan pengendalian.

\section{Seleksi Karyawan}

Menurut Hasibuan (2008:47), Seleksi adalah suatu kegiatan pemilihan dan penentuan pelamar yang diterima atau ditolak untuk menjadi karyawan dalam suatu perusahaan atau organisasi. Menurut Ambar Teguh (2009:15), seleksi adalah proses yang terdiri dari berbagai langkah yang spesifik dari kelompok pelamar yang paling cocok dan memenuhi syarat untuk jabatan tertentu. Proses seleksi juga merupakan upaya yang sistematis untuk mengimplementasikan rencana sumber daya manusia melalui pemilihan, evaluasi dan penyaringan atas karyawan yang memenuhi syarat. Analisis deskripsi tugas dan spesifikasi tugas merupakan alat yang sangat penting dan sangat membantu didalam organisasi melakukan penerimaan karyawan.

Menurut Siswanto (1989: 68-70) Seleksi adalah kegiatan suatu perusahaan untuk menentukan dan memilih tenaga kerja yang memenuhi kriteria yang telah di tetapkan oleh perusahaan serta memprediksi kemungkinan terhadap keberhasilan/kesuksesan atau kegagalan individu dalam pekerjaan yang akan di embannya.

Menurut Rivai(2008:65), seleksi adalah kegiatan dalam manajemen SDM yang dilakukan setelah proses rekrutmen seleksi dilaksanakan. Hal ini berarti telah terkumpul sejumlah pelamar yang memenuhi syarat untuk kemudian dipilih mana yang dapat ditetapkan sebagai karyawan dalam suatu perusahaan. Proses pemilihan ini yang dinamakan seleksi.

Menurut Sunyoto(2008:48) proses seleksi adalah usaha menjaring dari mereka yang dianggap nantinya bisa menyesuaikan diri dengan pekerjaan yang ditawarkan, mereka dianggap dapat memperlihatkan unjuk kerja yang diharapkan oleh para pimpinan organisasi.

Metode seleksi dikenal atas: "metode non ilmiah dan metode ilmiah". Metode non ilmiah, yaitu seleksi yang dilaksanakan tidak didasarkan kepada kriteria/standar atau spesifikasi kebutuhan nyata pekerjaan atau jabatan, tetapi hanya didasarkan kepada perkiraan dan pengalaman saja. Seleksi dalam hal ini tidak berpedoman kepada job description dan job specification dari jabatan yang akan diisi. Seleksi non ilmiah (observation method) ini, kurang dapat dipertanggung jawabkan, karena kualitas dan kuantitas karyawan yang diterima tidak sesuai dengan kebutuhan perusahaan bahkan sering menimbulkan mis management karyawan. Sedangkan metode ilmiah, adalah seleksi yang didasarkan kepada ilmu pengetahuan dan kebutuhan nyata jabatan yang akan diisi serta berpedoman kepada kriteria spesifikasi dan standar-standar tertentu. Dengan seleksi ilmiah ini diharapkan akan diperoleh karyawan yang qualified dan penempatannya yang tepat, sehingga pembinaannya dan pengembangannya relatif lebih mudah.

\section{Komunikasi}

Menurut Prabu Mangkunegara (2013:145) berpendapat “Komunikasi adalah proses pemindahan suatu informasi, pemindahan ide, pengertian, dari seseorang kepada orang lain dengan harapan orang lain tersebut dapat menginterpretasikannya sesuai dengan tujuan 
yang di maksud". Komunikasi merupakan pemindahan informasi dan pemahaman dari seseorang kepada seseorang. Untuk pemindahkan informasi yang dimaksud dalam komunikasi tersebut diperlukan suatu proses komunikasi. Menurut Webster New Collogiate Dictionary " istilah komunikasi berasal dari istilah Latin Communicare, bentuk past participle dari communication dan communicatus yang artinya suatu alat untuk berkomunikasi terutama suatu sistem penyampaian dan penerimaan berita, seperti mlsalnya telepon, telegrap, radio, dan lain sebagainya". Gibson dan Ivan (2012: 84) mengemukakan "Komunikasi adalah pengiriman informasi dan pemahaman, mengenai simbol verbal atau non verbal". "Komunikasi adalah proses pemindahan pengertian dalam bentuk gagasan atau informasi dari seseorang ke orang lain.

Luthan (2011:372) memberikan pengertian yang secara langsung mengarah pada perubahan dan perkembangan organisasi yang hanya dapat terjadi melalui pengembangan sumber daya manusia di lingkungan masing-masing. Untuk mencapai tujuan organisasi maka diperlukan sebuah komunikasi yang baik, di mana terdapat jalinan pengertian dalam komunikasi tersebut sehingga dapat dimengerti serta dilaksanakan antara pihak yang satu dengan pihak yang lain. Komunikasi ini sangat berperan dalam suatu organisasi untuk mencapai tujuannya Newstrom dan Davis (2004:151) mengemukakan bahwa “Apabila tidak ada komunikasi para karyawan tidak dapat mengetahui apa yang dilakukan rekan sekerjanya, pimpinan tidak dapat menerima masukan informasi, dan para penyelia tidak dapat memberikan instruksi". Robbins dan Timothy A. Judge yang dikutip oleh Wibowo (2013:255) menyebutkan bahwa "komuniksai membantu perkembangan motivasi dengan menjelaskan kepada para karyawan apa yang harus dilakukan, seberapa baik mereka bekerja, dan apa yang dapat dikerjakan untuk memperbaiki kinerja yang di bawah standar".

Salah satu prinsip dalam manajemen dan organisasi adalah kerja sama. Kerjasama dapat dilaksanakan dengan baik apabila terjadi komunikasi dialogis antara manajer dan bawahan dan diantara seluruh pekerja yang melaksanakan kegiatan organisasi (Athoillah dan Anton 2010:16). Dengan adanya respons, anggapan atau umpan balik yang diberikan oleh komunikan berarti pesan yang dikirim itu sudah sampai sehingga terjadi komunikasi dua.

Sedangkan menurut Haryani (2010:40-45)) komunikasi merupakan proses dimana seseorang (komunikator) biasanya dengan simbol-simbol verbal untuk mengubah perilaku dari orang lain (komunikan). Menurut Anwar Prabu Mangkunegara (2000:67) komunikasi adalah proses pemindahan suatu informasi, ide, pengertian dari seseorang ke orang lain tersebut dapat menginterprestasikannya sesuai dengan tujuan yang dimaksud.

Anwar Syaiful dan Supardi (2002:81) memaknai komunikasi sebagai usaha untuk mendorong orang lain untuk menginterprestasikan pendapat seperti apa yang dikehendaki oleh orang yang mempunyai pendapat tersebut. Dengan komunikasi diharapkan diperoleh titik persamaan, saling pengertian. Komunikasi mengandung arti yang lebih luas daripada sekedar mengatakan atau menuliskan sesuatu, di dalamnya juga tercakup suatu pengertian. Pada dasarnya organisasi atau perusahaan juga melakukan komunikasi, bahkan komunikasi bisnis lebih kompleks dibanding komunikasi individu. Komunikasi yang terjadi di dalam perusahaan ini selanjutnya disebut dengan komunikasi bisnis.

Dari definisi para ahli tersebut dapat diartikan bahwa komunikasi adalah proses penyampaian atau pemindahan suatu pesan, informasi, ide, atau pengertian dari seseorang kepada orang lain dengan harapan orang lain tersebut dapat menginterprestasikanya sesuai dengan tujuan yang dimaksud dan memperoleh pengertian atau persepsi yang sama.

\section{E. Prestasi Kerja Karyawan}

Menurut Umam (2010:199) berpendapat : “Prestasi kerja adalah suatu hasil yang dicapai oleh karyawan dalam mengerjakan tugas atau pekerjaannya secara efisien dan efektif". Menurut Edy Sutrisno (2013:150) berpendapat :"Prestasi kerja adalah hasil upaya seseorang yang di tentukan oleh kemampuan karakteristik pribadinya serta presepsi terhadap 
perannya dalam pekerjaan itu." Dari pengertian pendapat para ahli tersebut, dapat disimpulkan bahwa prestasi kerja adalah suatu hasil upaya atau kerja seseorang dalam mengerjakan tugas atau pekerjaannya secara efektif dan efisien yang ditentukan oleh kemamuan karakteristik pribadi serta persepsi terhadap perannya dalam pekerjaan itu.

Dengan demikian maka prestasi kerja karyawan merupakan suatu hasil yang dihasilkan dari suatu pekerjaan dimana waktunya telah ditetapkan sebelumnya atau suatu periode waktu tertentu. Dapat juga dikatakan sebagai hasil kerja secara kualitas atau kuantitas yang dicapai oleh seorang karyawan dalam melaksanakan tugasnya sesuai dengan tanggung jawab yang diberikan kepada karyawan.

\section{METODE PENELITIAN}

\section{A. Ruang Lingkup Penelitian}

Jenis penelitian yang digunakan adalah penelitian kuantitatif lapangan yaitu penelitian yang turun langsung kelapangan dimana peneliti ini dominan menggunakan angket untuk mendeskipsikan data yang penulis peroleh dari responden untuk memeroleh gambaran yang jelas dan terperinci terhadap pengaruh seleksi karyawan dan komunikasi terhadap prestasi kerja karyawan pada PT. Pelabuhan Indonesia I (Persero) Medan. Adapun ruang lingkup penelitian adalah seleksi karyawan, komunikasi dan prestasi kerja karyawan.

\section{B. Populasi dan Sampel}

Menurut Sugiyono (2008:80), pengertian populasi adalah wilayah generalisasi yang terdiri atas objek/subjek yang mempunyai kualitas dan karakteristik tertentu yang ditetapkan oleh peneliti untuk dipelajari dan kemudian ditarik kesimpulannya. Jadi, pengertian populasi dalam statistik tidak terbatas pada sekelompok/kumpulan orang-orang, namun mengacu pada seluruh ukuran, hitungan, atau kualitas yang menjadi fokus perhatian suatu kajian.

Adapun yang menjadi populasi dalam penelitian ini adalah bagian SDM PT. Pelabuhan Indonesia I (Persero) Medan yang berjumlah 123 orang.

Menurut Sugyono (2012:116) sampel merupakan sebagian dari anggota populasi. Penentuan jumlah sampel yang diambil sebagai responden dengan menggunakan rumus Slovin dalam Azuar (2013:62) sebagai berikut:

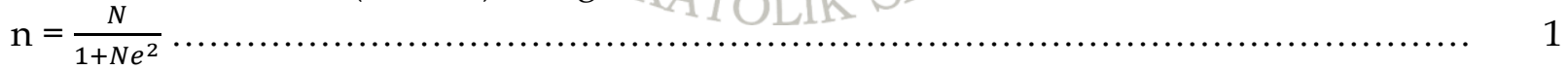

$$
\begin{aligned}
& \text { Keterangan }: \mathrm{n}=\text { Ukuran sampel } \\
& \mathrm{N}=\text { Ukuran Populasi } \\
& \mathrm{e}=\text { Persentase kelonggaran kesalahan ketidaktelitian karena kesalahan }
\end{aligned}
$$

Dengan rumus diatas diperoleh jumlah sampel sebagai berikut :

$$
\begin{aligned}
& \mathrm{n}=\frac{123}{1+123(0,1)^{2}} \\
& \mathrm{n}=\frac{123}{1+1,23} \\
& \mathrm{n}=\frac{123}{2,23} \\
& \mathrm{n}=55,16 \text { atau dibulatkan menjadi } 55 \text { orang }
\end{aligned}
$$

Jumlah sampel yang diambil sebanyak 55 orang.

\section{Operasionalisasi Variabel}

Operasionalisasi variabel adalah batasan pokok permasalahan yang diteliti dan diamati sesuai dengan perumusan masalah. Adapun variabel yang akan diteliti dalam penelitian ini adalah variabel bebas terdiri dari seleksi karyawan dan komunikasi. Sedangkan variabel terikat adalah prestasi kerja karyawan. Definisi operasional ketiga variabel tersebut dapat dilihat dalam tabel 3.1 berikut. 
Tabel 1 Operasionalisasi Variabel

\begin{tabular}{|c|c|c|c|}
\hline Variabel & Definisi Operasional & Indikator & Skala \\
\hline $\begin{array}{c}\text { Seleksi } \\
\text { Karya } \\
\text { wan }\left(\mathrm{X}_{1}\right)\end{array}$ & $\begin{array}{l}\text { Suatu kegiatan pemilihan dan penentuan } \\
\text { pelamar yang diterima atau ditolak untuk } \\
\text { menjadi karyawan perusahaan } \\
\text { Sumber: Hasibuan (2008:47) }\end{array}$ & $\begin{array}{l}\text { 1. Pendidikan } \\
\text { 2. Kecakapan } \\
\text { 3. Keterampilan } \\
\text { 4. Keahlian } \\
\text { 5. Kesehatan fisik } \\
\text { 6. Umur }\end{array}$ & Likert \\
\hline $\begin{array}{l}\text { Komuni } \\
\text { kasi }\left(X_{2}\right)\end{array}$ & $\begin{array}{l}\text { Komunikasi adalah proses pemindahan } \\
\text { suatu informasi, pemindahan ide, } \\
\text { pengertian, dari seseorang kepada orang } \\
\text { lain dengan harapan orang lain tersebut } \\
\text { dapat menginter pretasikannya sesuai } \\
\text { dengan tujuan yang di maksud. } \\
\text { Sumber: Anwar Prabu Mangkunegara } \\
\text { (2013:145) }\end{array}$ & $\begin{array}{l}\text { 1. Kemudahan } \\
\text { memperoleh informasi } \\
\text { 2. Intensitas komunikasi } \\
\text { 3. Efektivitas } \\
\text { komunikasi } \\
\text { 4. Tingkat pemahaman } \\
\text { pesan } \\
\text { 5. Perubahan sikap }\end{array}$ & Likert \\
\hline $\begin{array}{l}\text { Prestasi } \\
\text { Kerja } \\
\text { Karya } \\
\text { wan }(\mathrm{Y})\end{array}$ & $\begin{array}{l}\text { Prestasi kerja dalah suatu hasil yang } \\
\text { dicapai oleh karyawan dalam } \\
\text { mengerjakan tugas atau pekerjaanya } \\
\text { secara efisien dan efektif. } \\
\text { Sumber: Khaerul Umam (2010:199) }\end{array}$ & $\begin{array}{l}\text { 1. Kualitas kerja } \\
\text { 2. Kuantitas kerja } \\
\text { 3. Disiplin kerja } \\
\text { 4. Inisiatif } \\
\text { 5. Kerjasama }\end{array}$ & Likert \\
\hline
\end{tabular}

Sumber: Hasil Olahan Penulis

Skala pengukuran variabel yang digunakan adalah skala likert. Menurut Sugiyono (2008:132), "skala likert digunakan untuk mengukur sikap, pendapat dan persepsi seseorang atau sekelompok orang tentang fenomena sosial".

\section{Skala Pengukuran Variabel}

Menurut Sugyono (2008:132), skala likert digunakan untuk mengukur sikap, pendapat, dan persepsi seseorang atau sekelompok orang tentang fenomena sosial.

Setiap jawaban diberi skor dengan berdasarkan pada skala likert dengan angka atau bobot yaitu 1 sampai dengan 5 .

Tabel 2 Skala Pengukuran Variabel

\begin{tabular}{|l|c|c|}
\hline \multicolumn{1}{|c|}{ Pernyataan } & Jawaban & Bobot Nilai \\
\hline Sangat Setuju & SS & 5 \\
Setuju & S & 4 \\
Kurang Setuju & KS & 3 \\
Tidak Setuju & TS & 2 \\
Sangat Tidak Setuju & STS & 1 \\
\hline
\end{tabular}

\section{E. Teknik Pengumpuan Data}

Teknik pengumpulan data dalam penelitian ini diantaranya yaitu sebagai berikut:

a. Wawancara. Wawancara digunakan sebagai teknik pengumpulan data apabila peneliti ingin melakukan studi pendahuluan untuk menemukan masalah yang harus diteliti dan juga apabila peneliti ingin mengetahui hal-hal dari responden yang lebih mendalam dan jumlah respondenya sedikit. Wawancara dapat dilakukan secara terstruktur mapun tidak terstruktur dan dapat dilakukan secara langsung maupun tidak langsung.

b. Kuesioner. Kuesioner merupakan teknik pengumpulan data yang dilakukan dengan cara memberi seperangkat pertanyaan dan pernyataan tertulis kepada responden untuk dijawabnya. Kelebihan menggunakan kuesioner adalah dalam waktu yang relatif singkat 
dapat memperoleh data yang banyak, tenaga yang diperlukan sedikit dan responden dapat menjawab dengan bebas tanpa pengaruh orang lain. Sedangkan kelemahan kuesioer adalah angket bersifat kaku karena pertanyaan telah ditentukan dan responden tidak memberi jawaban yang sesuai dengan keadaan dirinya hanya sekedar membaca kemudian menulis jawabannya.

c. Studi Dokumentasi. Dokumentasi adalah kumpulan dari dokumen-dokumen yang dapat memberikan keterangan atau bukti yang berkaitan dengan proses pengumpulan dan pengelolaan dokumen secara sistematis serta menyebarluaskan kepada pemakai informasi tersebut. Peneliti memperoleh data dan dokumen-dokumen tertulis. Penulis membaca dan mempelajari berbagai tulisan dari buku-buku, jurnal-jurnal, dan internet yang berkaitan dan mendukung kebenaran dan keabsahan dari hasil yang diperoleh dari penelitian ini.

\section{F. Uji Validitas}

Uji validitas adalah suatu data dapat dipercaya kebenarannya sesuai dengan kenyataan. Menurut Sugyono (2009:172) bahwa valid berarti instrumen tersebut dapat digunakan untuk mengukur apa yang sebenarnya diukur. Valid menunjukkan derajat ketepatan antara data yang sesungguhnya terjadi pada objek dengan data yang dapat dikumpulkan oleh peneliti.

Uji validitas dalam penelitian ini digunakan analisis item yaitu mengkorelasikan skor tiap dengan skor total yang merupakan jumlah dari tiap skor butir. Jika ada item yang tidak memenuhi syarat, maka item tersebut tidak akan diteliti lebih lanjut. Syarat tersebut menurut Sugyono (2009:179) sebagai berikut :

a. Jika $r \geq 0,30$, maka item-item pernyataan dari kuesioner adalah valid

b. Jika $r \leq 0,30$, maka item-item pernyataan dari kuesioner adalah tidak valid

\section{G. Uji Reliabilitas}

Uji reliabilitas digunakan untuk menguji apakah hasil kuesioner dapat dipercaya atau tidak. Menurut Sugyono (2008:185), “penguji reliabilitas dengan menggunakan internet consistency, dilakukan dengan cara mencoba instrumen sekali saja, kemudian data yang diperoleh dianalisis dengan teknik tertentu".

Penguji reliabilitas instrumen dilakukan dengan menggunakan rumus Spearmen Brown, yaitu dengan rumus :

$$
\mathrm{ri}=\frac{2 r b}{1+r b}
$$

Dimana : ri = Reliabilitas internal seluruh instrumen

$\mathrm{rb}=$ Korelasi product moment antara belahan pertama dan kedua

Perhitungan reliabilitas pada penelitian ini menggunakan analisis yang dikembangkan oleh Alpha Croncbach, dengan kriteria sebagai berikut :

$a>0,50$ artinya instrumen reliable

$a<0,50$ artinya instrumen tidak reliable

Pengujian dilakukan dengan menggunakan program statistical package for social sciences (SPSS) versi 22.

\section{H. Metode Analisis Regresi Berganda}

Teknik analisis yang digunakan adalah persamaan regresi linear berganda yang berguna untuk mengetahui pengaruh Seleksi Karyawan dan Komunikasi Terhadap Prestasi Kerja Karyawan (Sugiyono, 2008:277), dengan rumus:

$Y=a+\beta_{1} X_{1}+\beta_{2} X_{2}+e i$

Dimana $: Y=$ Variabel dependen (Prestasi Kerja Karyawan)

$\mathrm{a}=$ Konstanta

$\beta_{1}=$ Koefisien variabel bebas 1

$\beta_{2}=$ Koefisien variabel bebas 2 
$\mathrm{X}_{1}, \mathrm{X}_{2}=$ Variabel independen (Seleksi Karyawan, Komunikasi)

ei $=$ error $/$ Tingkat kesalahan estimasi menjadi:

Kemudian persamaan regresi berganda diatas diaplikasikan dalam penelitian ini

$\mathrm{PK}=\mathrm{a}+\beta_{1} \mathrm{SK}+\beta_{2} \mathrm{~K}+\mathrm{ei}$

Dimana:

PK $\quad=$ Prestasi Kerja

SK = Seleksi Karyawan

$\mathrm{K} \quad=$ Komunikasi

$$
\begin{array}{cl}
\beta_{1}, \beta_{2} & =\text { Koefisien regresi } \\
\mathrm{a} & =\text { Konstanta } \\
\mathrm{ei} & =\text { Standar eror }
\end{array}
$$

\section{Uji Hipotesis}

Pengujian ini dilakukan untuk membuktikan apakah $\mathrm{H}_{0}$ dan $\mathrm{H}_{1}$ ditolak atau diterima, dengan prosedur pengujian sebagai berikut:

Uji F untuk mengetahui pengaruh secara simultan (menyeluruh)

1. $\mathrm{H}_{0}: \beta_{\mathrm{i}} \leq 0$, artinya seleksi karyawan dan komunikasi tidak berpengaruh positif dan signifikan secara simultan terhadap prestasi kerja karyawan pada PT. Pelabuhan Indonesia I (Persero) Medan.

2. $\mathrm{H}_{1}: \beta_{\mathrm{i}}>0$, artinya seleksi karyawan dan komunikasi berpengaruh positif dan signifikan secara simultan terhadap prestasi kerja karyawan pada PT. Pelabuhan Indonesia I (Persero) Medan.

3. Level of significant atau alpha sebesar (a) $5 \%$ (uji satu arah).

4. Uji statistik F Sugiyono (2008:257) :

$$
F h=\frac{R^{2} / k}{\left(1-R^{2}\right) /(n-k-1)}
$$

$$
\begin{aligned}
& \mathrm{F}_{\mathrm{h}}=\mathrm{F}_{\text {hitung }} \\
& \mathrm{k} \equiv \text { Jumlah variabel bebas }
\end{aligned}
$$

$$
\begin{aligned}
& \mathrm{n}=\text { Jumlah sampel } \\
& \mathrm{R}^{2}=\mathrm{R} \text { Square }
\end{aligned}
$$

5. Kriteria keputusan: Jika nilai signifikansi a $\leq 0,5$, maka $\mathrm{H}_{0}$ ditolak dan $\mathrm{H}_{1}$ diterima. Jika nilai signifikansi a $>0,5$, maka $\mathrm{H}_{0}$ diterima dan $\mathrm{H}_{1}$ ditolak.

6. Kesimpulan : Dapat disimpulkan apakah hipotesis diterima atau ditolak.

Uji t untuk mengetahui pengaruh secara parsial (satu per satu)

1. $\mathrm{H}_{0}: \beta_{\mathrm{i}} \leq 0$, artinya seleksi karyawan dan komunikasi tidak berpengaruh positif dan signifikan secara parsial terhadap prestasi kerja karyawan pada PT. Pelabuhan Indonesia I (Persero) Medan.

2. $\mathrm{H}_{1}: \beta_{\mathrm{i}}>0$, artinya seleksi karyawan dan komunikasi berpengaruh positif dan signifikan secara parsial terhadap prestasi kerja karyawan pada PT. Pelabuhan Indonesia I (Persero) Medan.

3. Level of significant atau alpha sebesar (a) $5 \%$ (uji satu arah).

4. Statistik uji $\mathrm{t}$

$$
\mathrm{t}=\frac{b}{S b}
$$

Dimana :

$$
\begin{aligned}
& \mathrm{t}=\mathrm{t}_{\text {hitung }} \\
& \mathrm{b}=\text { Koefisien regresi } \\
& \mathrm{Sb}=\text { Standar error of estimate }
\end{aligned}
$$

5. Kriteria keputusan:

Jika nilai signifikansi a $\leq 0,5$, maka $\mathrm{H}_{0}$ ditolak dan $\mathrm{H}_{1}$ diterima.

Jika nilai signifikansi a $>0,5$, maka $\mathrm{H}_{0}$ diterima dan $\mathrm{H}_{1}$ ditolak..

\section{J. Koefisien Determinasi $\left(\mathbf{R}^{2}\right)$}

Koefisien determinasi $\left(\mathrm{R}^{2}\right)$ pada intinya mengukur seberapa besar kemampuan model dalam menerangkan variabel terikat. Jika $\mathrm{R}^{2}$ semakin besar (mendekati nol), maka dapat dikatakan bahwa pengaruh variabel bebas $(X)$ semakin besar terhadap variabel terikat $(Y)$. Hal 
ini berarti model yang digunakan semakin kuat untuk menerangkan pengaruh variabel bebas yag diteliti terhadap variabel terikat. Sebaliknya jika $\mathrm{R}^{2}$ semakin mengecil (menjauhi nol), maka dapat dikatakan bahwa pengaruh variabel bebas $(X)$ terhadap variabel terikat $(Y)$ semakin kecil. Hal ini berarti model yang digunakan tidak kuat untuk menerangkan pengaruh variabel bebas yang diteliti terhadap variabel terikat.

\section{HASIL PENELITIAN DAN PEMBAHASAN}

Identitas responden yang dijadikan sebagai sampel dalam penelitian ini terdiri dari jenis kelamin dan status seperti yang disajikan pada tabel berikut ini:

Tabel 3. Jumlah Responden Berdasarkan Jenis Kelamin

\begin{tabular}{|l|c|c|}
\hline Jenis kelamin & Jumlah & Persentase \% \\
\hline Laki - laki & 34 & $61,82 \%$ \\
\hline Perempuan & 21 & $38,18 \%$ \\
\hline Jumlah & 55 & $100 \%$ \\
\hline
\end{tabular}

Sumber: Diolah dari lampiran 1

Dari tabel 3. ditunjukkan jenis kelamin responden yang dijadikan sebagai sampel penelitian adalah laki- laki $34(61,82 \%)$ orang dan perempuan $21(38,18 \%)$ orang. Hal ini menunjukkan bahwa responden pada PT. Pelabuhan Indonesia I (Persero) Medan di bagian SDM sangat didominasi berjenis kelamin laki- laki.

Tabel 4. Jumlah Responden Berdasarkan Status

\begin{tabular}{|l|c|c|}
\hline \multicolumn{1}{|c|}{ Status } & Jumlah & Persentase \% \\
\hline Belum menikah & 30 & $54,55 \%$ \\
\hline Menikah & 25 & $45,45 \%$ \\
\hline Jumlah & 55 & $100 \%$ \\
\hline
\end{tabular}

Sumber: Data dari lampiran 1

Dari tabel 4. ditunjukkan bahwa status responden yang dijadikan sebagai sampel penelitian adalah responden yang sudah menikah $25(45,45 \%)$ orang dan responden yang belum menikah $30(54,55 \%)$ orang. Hal ini menunjukkan bahwa responden pada PT. Pelabuhan Indonesia I (Persero) Medan di bagian SDM lebih dominan belum menikah.

Tabel 5. Jumlah Responden Berdasarkan Pendidikan Terakhir

\begin{tabular}{|l|c|c|}
\hline Pendidikan terakhir & Jumlah & Persentase \% \\
\hline SMA/SMK & 6 & $10,91 \%$ \\
\hline Diploma & 13 & $23,64 \%$ \\
\hline S1 & 26 & $47,27 \%$ \\
\hline S2 & 10 & $18,18 \%$ \\
\hline Jumlah & 55 & $100 \%$ \\
\hline
\end{tabular}

Sumber : Data diolah dari lampiran 1

Dari tabel 5. menunjukkan pendidikan terakhir responden yang dijadikan sebagai sampel penelitian adalah SMA/SMK berjumlah 6 orang $(10,91 \%)$, Diploma berjumlah 13 orang $(23,64 \%)$, S1 berjumlah 26 orang $(47,27 \%)$ dan S2 berjumlah 10 orang $(18,18 \%)$ dari total responden.

Tabel 6 Jumlah Responden Berdasarkan Usia

\begin{tabular}{|c|c|c|}
\hline Usia & Jumlah & Persentase (\%) \\
\hline $20-35$ tahun & 38 orang & $69,09 \%$ \\
\hline
\end{tabular}




\begin{tabular}{|c|c|c|}
\hline Usia & Jumlah & Persentase (\%) \\
\hline $35-40$ tahun & 17 orang & $30,91 \%$ \\
\hline Jumlah & 55 orang & $100 \%$ \\
\hline
\end{tabular}

Sumber : Data diolah dari lampiran 1

Dari tabel 6 menunjukkan usia responden yang dijadikan sebagai sampel penelitian adalah dari usia 20-35 tahun berjumlah 38 orang $(69,09 \%)$, dan dari usia 35-40 tahun berjumlah 17 orang $(30,91 \%)$ dari total responden.

\section{A. Tanggapan Responden Tentang Seleksi Karyawan}

Berdasarkan lampiran 2, diketahui jumlah dan persentase jawaban responden mengenai seleksi karyawan pada PT. Pelabuhan Indonesia I (Persero) Medan yang disajikan pada tabel 7 berikut:

Tabel 7 Persentase Skor Jawaban Responden Mengenai Seleksi Karyawan

\begin{tabular}{|c|c|c|c|c|c|c|c|c|c|c|c|}
\hline $\mathrm{No}$ & Pernyataan & \multicolumn{2}{|c|}{ SS } & \multicolumn{2}{|c|}{$S$} & \multicolumn{2}{|c|}{ KS } & \multicolumn{2}{|c|}{ TS } & \multicolumn{2}{|c|}{ STS } \\
\hline 1 & $\begin{array}{l}\text { Latar belakang pendidikan } \\
\text { sebaiknya dijadikan syarat } \\
\text { utama dalam menyeleksi } \\
\text { tenaga kerja }\end{array}$ & 10 & $18 \%$ & 24 & $\%$ & & $\begin{array}{c}25 \\
\%\end{array}$ & 8 & $14 \%$ & 0 & $0 \%$ \\
\hline 2 & $\begin{array}{l}\text { Kecakapan seorang pelamar } \\
\text { juga perlu dilihat dalam } \\
\text { menyeleksi calon karyawan }\end{array}$ & 9 & $16 \%$ & 15 & $\begin{array}{l}27 \\
\%\end{array}$ & 18 & $\begin{array}{c}33 \\
\%\end{array}$ & $\begin{array}{l}1 \\
0\end{array}$ & $18 \%$ & 3 & $6 \%$ \\
\hline 3 & $\begin{array}{l}\text { Dalam menyeleksi para calon } \\
\text { karyawan perlu diadakan tes } \\
\text { keterampilan masing-masing } \\
\text { calon karyawan sesuai } \\
\text { dengan jenis pekerjaan yang } \\
\text { akan dikerjakan nanti di } \\
\text { perusahaan }\end{array}$ & 6 & $11 \%$ & 21 & $\begin{array}{c}38 \\
\%\end{array}$ & & 27 & $\begin{array}{l}1 \\
1\end{array}$ & $20 \%$ & 2 & $4 \%$ \\
\hline 4 & $\begin{array}{l}\text { Pertanyaan yang diadakan } \\
\text { oleh pewawancara } \\
\text { berhubungan } \\
\text { pekerjaan yang ditawarkan } \\
\text { seperti keahlian mengenai } \\
\text { bidang tertentu }\end{array}$ & 1 & $2 \%$ & 24 & $\begin{array}{l}43 \\
\%\end{array}$ & 19 & $\begin{array}{c}35 \\
\%\end{array}$ & 5 & $9 \%$ & 6 & $\begin{array}{l}11 \\
\%\end{array}$ \\
\hline 5 & $\begin{array}{l}\text { Perusahaan meminta data } \\
\text { mengenai riwayat kesehatan } \\
\text { fisik calon karyawan }\end{array}$ & 4 & $7 \%$ & 14 & $\begin{array}{l}25 \\
\%\end{array}$ & 24 & $\begin{array}{c}44 \\
\%\end{array}$ & $\begin{array}{l}1 \\
1\end{array}$ & $20 \%$ & 2 & $4 \%$ \\
\hline 6 & $\begin{array}{l}\text { Perusahaan memperlihatkan } \\
\text { dan membatasi umur calon } \\
\text { karyawan yang ingin di } \\
\text { seleksi }\end{array}$ & 6 & $11 \%$ & 19 & $\begin{array}{c}35 \\
\%\end{array}$ & 17 & $\begin{array}{c}31 \\
\%\end{array}$ & $\begin{array}{l}1 \\
0\end{array}$ & $18 \%$ & 3 & $5 \%$ \\
\hline
\end{tabular}

Sumber : Diolah dari lampiran 2

Dari tabel diatas responden yang menyatakan sangat setuju bahwa latar belakang pendidikan sebaiknya dijadikan syarat utama dalam menyeleksi tenaga kerja sebanyak 10 orang $(18 \%)$, setuju 24 orang (43\%), kurang setuju 14 orang (25\%), tidak setuju 8 orang (14\%) dan responden yang menyatakan sangat tidak setuju 0 orang $(0 \%)$. Dari jawaban diatas, bahwa responden mayoritas menjawab setuju yaitu sebanyak 24 orang (43\%). 
Responden yang menyatakan sangat setuju bahwa kecakapan seorang pelamar juga perlu dilihat dalam menyeleksi calon karyawan sebanyak 9 orang (16\%), setuju 15 orang $(27 \%)$, kurang setuju 18 orang $(33 \%)$, tidak setuju 10 orang $(18 \%)$ dan responden yang menyatakan sangat tidak setuju 3 orang $(6 \%)$. Dari jawaban diatas, bahwa responden mayoritas menjawab kurang setuju yaitu sebanyak 18 orang (33\%).

Responden yang menyatakan sangat setuju bahwa dalam menyeleksi para calon karyawan perlu diadakan tes keterampilan masing-masing calon karyawan sesuai dengan jenis pekerjaan yang akan dikerjakan nanti di perusahaan sebanyak 6 orang (11\%), setuju 21 orang $(38 \%)$, kurang setuju 15 orang $(27 \%)$, tidak setuju 11 orang $(20 \%)$ dan responden yang menyatakan sangat tidak setuju 2 orang (4\%). Dari jawaban diatas, bahwa responden mayoritas menjawab setuju yaitu sebanyak 21 orang (38\%).

Responden yang menyatakan sangat setuju bahwa pertanyaan yang diadakan oleh pewawancara berhubungan dengan pekerjaan yang ditawarkan seperti keahlian mengenai bidang tertentu sebanyak 1 orang (2\%), setuju 24 orang (43\%), kurang setuju 19 orang (35\%) , tidak setuju 5 orang (9\%) dan responden yang menyatakan sangat tidak setuju 6 orang (11\%). Dari jawaban diatas, bahwa responden mayoritas menjawab setuju yaitu sebanyak 24 orang $(43 \%)$.

Responden yang menyatakan sangat setuju bahwa perusahaan meminta data mengenai riwayat kesehatan fisik calon karyawan sebanyak 4 orang $(7 \%)$, setuju 14 orang $(25 \%)$, kurang setuju 24 orang $(44 \%)$, tidak setuju 11 orang $(20 \%)$ dan responden yang menyatakan sangat tidak setuju 2 orang (4\%). Dari jawaban diatas, bahwa responden mayoritas menjawab kurang setuju yaitu sebanyak 24 orang $(44 \%)$.

Responden yang menyatakan sangat setuju bahwa perusahaan memperlihatkan dan membatasi umur calon karyawan yang ingin di seleksi sebanyak 6 orang (11\%), setuju 19 orang (35\%), kurang setuju 17 orang (31\%), tidak setuju 10 orang (18\%) dan responden yang menyatakan sangat tidak setuju 3 orang (5\%). Dari jawaban diatas, bahwa responden mayoritas menjawab setuju yaitu sebanyak 19 orang (35\%).

\section{B. Tanggapan Responden Tentang Komunikasi}

Berdasarkan lampiran 2, diketahui jumlah dan persentase jawaban responden mengenai komunikasi pada PT. Pelabuhan Indonesia I (Persero) Medan yang disajikan pada tabel 8 berikut:

Tabel 8 Persentase Skor Jawaban Responden Mengenai Komunikasi

\begin{tabular}{|c|l|c|c|c|c|c|c|c|c|c|c|}
\hline No & \multicolumn{1}{|c|}{ Pernyataan } & \multicolumn{2}{|c|}{ SS } & \multicolumn{2}{|c|}{ S } & \multicolumn{2}{c|}{ KS } & \multicolumn{2}{|c|}{ TS } & \multicolumn{2}{|c|}{ STS } \\
\hline 1 & $\begin{array}{l}\text { Saya selalu menggunakan surat } \\
\text { pengumuman dan memo sebagai } \\
\text { media komunikasi guna } \\
\text { mempermudah memperoleh }\end{array}$ & 7 & $\begin{array}{c}13 \\
\text { informasi }\end{array}$ & 21 & $\begin{array}{c}38 \\
\%\end{array}$ & 15 & $\begin{array}{c}27 \\
\%\end{array}$ & 8 & $\begin{array}{c}15 \\
\%\end{array}$ & 4 & $7 \%$ \\
\hline 2 & $\begin{array}{l}\text { Jika komunikasi antar karyawan } \\
\text { baik, maka akan meningkatkan } \\
\text { intensitas komunikasi dalam } \\
\text { mencapai prestasi kerja }\end{array}$ & 11 & 20 & 19 & $\begin{array}{c}35 \\
\%\end{array}$ & 16 & $\begin{array}{c}29 \\
\%\end{array}$ & 8 & $\begin{array}{c}15 \\
\%\end{array}$ & 1 & $1 \%$ \\
\hline 3 & $\begin{array}{l}\text { Saya selalu berkomunikasi dengan } \\
\text { tatap muka agar membuat } \\
\text { komunikasi efektif dan lebih baik }\end{array}$ & 10 & $\begin{array}{c}18 \\
\%\end{array}$ & 26 & $\begin{array}{c}47 \\
\%\end{array}$ & 11 & $\begin{array}{c}20 \\
\%\end{array}$ & 8 & $\begin{array}{c}15 \\
\%\end{array}$ & 0 & $0 \%$ \\
\hline 4 & $\begin{array}{l}\text { Jika penyampaian pesan dilakukan } \\
\text { dengan baik, maka pemahaman } \\
\text { pesan tersebut akan mudah } \\
\text { diterima }\end{array}$ & 11 & 20 & 23 & 42 & 14 & $\begin{array}{c}25 \\
\%\end{array}$ & 7 & $\begin{array}{c}13 \\
\%\end{array}$ & 0 & $0 \%$ \\
\hline
\end{tabular}




\begin{tabular}{|c|l|c|c|c|c|c|c|c|c|c|c|}
\hline No & \multicolumn{1}{|c|}{ Pernyataan } & \multicolumn{2}{|c|}{ SS } & \multicolumn{2}{|c|}{ S } & \multicolumn{2}{|c|}{ KS } & \multicolumn{2}{|c|}{ TS } & \multicolumn{2}{|c|}{ STS } \\
\hline 5 & $\begin{array}{l}\text { Jika sebuah komunikasi baik, maka } \\
\text { akan mempengaruhi perubahan } \\
\text { sikap orang lain untuk bersikap } \\
\text { positif sesuai dengan keinginan }\end{array}$ & 11 & $\begin{array}{c}20 \\
\%\end{array}$ & 22 & $\begin{array}{c}40 \\
\%\end{array}$ & 14 & $\begin{array}{c}26 \\
\%\end{array}$ & 7 & $\begin{array}{c}13 \\
\%\end{array}$ & 1 & $1 \%$ \\
\hline
\end{tabular}

Sumber : Diolah dari lampiran 2

Dari tabel diatas responden yang menyatakan sangat setuju bahwa saya selalu menggunakan surat pengumuman dan memo sebagai media komunikasi guna mempermudah memperoleh informasi sebanyak 7 orang $(13 \%)$, setuju 21 orang (38\%), kurang setuju 15 orang $(27 \%)$, tidak setuju 8 orang $(15 \%)$ dan responden yang menyatakan sangat tidak setuju 4 orang (7\%). Dari jawaban diatas, bahwa responden mayoritas menjawab setuju yaitu sebanyak 21 orang (38\%).

Responden yang menyatakan sangat setuju bahwa jika komunikasi antar karyawan baik, maka akan meningkatkan intensitas komunikasi dalam mencapai prestasi kerja sebanyak 11 orang (20\%), setuju 19 orang (35\%), kurang setuju 16 orang (29\%), tidak setuju 8 orang $(15 \%)$ dan responden yang menyatakan sangat tidak setuju 1 orang (\%). Dari jawaban diatas, bahwa responden mayoritas menjawab setuju yaitu sebanyak 19 orang (35\%).

Responden yang menyatakan sangat setuju bahwa saya selalu berkomunikasi dengan tatap muka agar membuat komunikasi efektif dan lebih baik sebanyak 10 orang (18\%), setuju 26 orang $(47 \%)$, kurang setuju 11 orang $(20 \%)$, tidak setuju 8 orang $(15 \%)$ dan responden yang menyatakan sangat tidak setuju 0 orang $(0 \%)$. Dari jawaban diatas, bahwa responden mayoritas menjawab setuju yaitu sebanyak 26 orang ( $47 \%)$.

Responden yang menyatakan sangat setuju bahwa jika penyampaian pesan dilakukan dengan baik, maka pemahaman pesan tersebut akan mudah diterima sebanyak 11 orang $(20 \%)$, setuju 23 orang ( $42 \%)$, kurang setuju 14 orang $(25 \%)$, tidak setuju 7 orang $(13 \%)$ dan responden yang menyatakan sangat tidak setuju 0 orang $(0 \%)$. Dari jawaban diatas, bahwa responden mayoritas menjawab setuju yaitu sebanyak 23 orang $(42 \%)$.

Responden yang menyatakan sangat setuju bahwa jika sebuah komunikasi baik, maka akan mempengaruhi perubahan sikap orang lain untuk bersikap positif sesuai dengan keinginan sebanyak 11 orang (20\%), setuju 22 orang ( $40 \%)$, kurang setuju 14 orang $(26 \%)$, tidak setuju 7 orang (13\%) dan responden yang menyatakan sangat tidak setuju 1 orang (1\%). Dari jawaban diatas, bahwa responden mayoritas menjawab setuju yaitu sebanyak 22 orang $(40 \%)$.

\section{Tanggapan Responden Prestasi Kerja Karyawan}

Berdasarkan lampiran 2, diketahui jumlah dan persentase jawaban responden mengenai prestasi kerja karyawan pada PT. Pelabuhan Indonesia I (Persero) Medan yang disajikan pada tabel 9 berikut:

Tabel 9 Persentase Skor Jawaban Responden Mengenai Prestasi Kerja Karyawan

\begin{tabular}{|c|l|c|c|c|c|c|c|c|c|c|c|}
\hline No & \multicolumn{1}{|c|}{ Pernyataan } & \multicolumn{2}{|c|}{ SS } & \multicolumn{2}{|c|}{ S } & \multicolumn{2}{c|}{ KS } & \multicolumn{2}{|c|}{ TS } & \multicolumn{2}{|c|}{ STS } \\
\hline 1 & $\begin{array}{l}\text { Saya mampu mencapai target } \\
\text { berdasarkan syarat-syarat } \\
\text { yang diberikan }\end{array}$ & $\begin{array}{c}1 \\
5\end{array}$ & $\begin{array}{c}27 \\
\%\end{array}$ & 19 & $\begin{array}{c}35 \\
\%\end{array}$ & $\begin{array}{c}1 \\
1\end{array}$ & $\begin{array}{c}20 \\
\%\end{array}$ & 6 & $11 \%$ & 4 & $7 \%$ \\
\hline 2 & $\begin{array}{l}\text { Saya akan menyelesaikan } \\
\text { pekerjaan dalam periode } \\
\text { waktu yang ditentukan }\end{array}$ & $\begin{array}{r}1 \\
5\end{array}$ & $\begin{array}{c}27 \\
\%\end{array}$ & 23 & $\begin{array}{c}42 \\
\%\end{array}$ & $\begin{array}{c}1 \\
0\end{array}$ & $\begin{array}{c}18 \\
\%\end{array}$ & 6 & $\begin{array}{c}11 \\
\%\end{array}$ & 1 & $2 \%$ \\
\hline $\begin{array}{l}\text { Saya selalu aktif dan semangat } \\
\text { dalam menyelesaikan } \\
\text { pekerjaan tanpa menunggu } \\
\text { perintah atasan }\end{array}$ & 9 & $\begin{array}{c}16 \\
\%\end{array}$ & 26 & $\begin{array}{c}47 \\
\%\end{array}$ & $\begin{array}{c}1 \\
8\end{array}$ & $\begin{array}{c}33 \\
\%\end{array}$ & 1 & $2 \%$ & 1 & $2 \%$ \\
\hline
\end{tabular}




\begin{tabular}{|c|c|c|c|c|c|c|c|c|c|c|c|}
\hline No & Pernyataan & \multicolumn{2}{|c|}{ SS } & \multicolumn{2}{|c|}{$S$} & \multicolumn{2}{|c|}{ KS } & \multicolumn{2}{|c|}{ TS } & \multicolumn{2}{|c|}{ STS } \\
\hline 4 & $\begin{array}{l}\text { Saya mengajak anggota } \\
\text { karyawan lain untuk dapat } \\
\text { saling menunjukkan } \\
\text { kemampuan masing-masing } \\
\text { dalam bekerja }\end{array}$ & $\begin{array}{l}1 \\
1\end{array}$ & $\begin{array}{c}20 \\
\%\end{array}$ & 24 & $\begin{array}{c}44 \\
\%\end{array}$ & $\begin{array}{l}1 \\
4\end{array}$ & $\begin{array}{c}25 \\
\%\end{array}$ & 6 & $\begin{array}{l}11 \\
\%\end{array}$ & 0 & $0 \%$ \\
\hline 5 & $\begin{array}{l}\text { Saya menunjukkan suatu ide } \\
\text { dan gagasan dalam } \\
\text { menyelesaikan suatu } \\
\text { persoalan }\end{array}$ & 7 & $\begin{array}{c}13 \\
\%\end{array}$ & 23 & $\begin{array}{c}42 \\
\%\end{array}$ & $\begin{array}{l}1 \\
9\end{array}$ & $\begin{array}{c}34 \\
\%\end{array}$ & 6 & $\begin{array}{l}11 \\
\%\end{array}$ & 0 & $0 \%$ \\
\hline
\end{tabular}

Sumber : Diolah dari lampiran 2

Dari tabel diatas responden yang menyatakan sangat setuju bahwa saya mampu mencapai target berdasarkan syarat-syarat yang diberikan sebanyak 15 orang (27\%), setuju 19 orang $(35 \%)$, kurang setuju 11 orang $(20 \%)$, tidak setuju 6 orang $(11 \%)$ dan responden yang menyatakan sangat tidak setuju 4 orang $(7 \%)$. Dari jawaban diatas, bahwa responden mayoritas menjawab setuju yaitu sebanyak 19 orang $(35 \%)$.

Responden yang menyatakan sangat setuju bahwa saya akan menyelesaikan pekerjaan dalam periode waktu yang ditentukan sebanyak 15 orang $(27 \%)$, setuju 23 orang (42\%), kurang setuju 10 orang $(18 \%)$, tidak setuju 6 orang $(11 \%)$ dan responden yang menyatakan sangat tidak setuju 1 orang (2\%). Dari jawaban diatas, bahwa responden mayoritas menjawab setuju yaitu sebanyak 23 orang (42\%).

Responden yang menyatakan sangat setuju bahwa saya selalu aktif dan semangat dalam menyelesaikan pekerjaan tanpa menunggu perintah atasan sebanyak 9 orang (16\%), setuju 27 orang (49\%), kurang setuju 18 orang (33\%), tidak setuju 1 orang $(2 \%)$ dan responden yang menyatakan sangat tidak setuju 1 orang (2\%). Dari jawaban diatas, bahwa responden mayoritas menjawab setuju yaitu sebanyak 27 orang (49\%).

Responden yang menyatakan sangat setuju bahwa saya mengajak anggota karyawan lain untuk dapat saling menunjukkan kemampuan masing-masing dalam bekerja sebanyak 11 orang (20\%), setuju 24 orang (44\%), kurang setuju 14 orang $(25 \%)$, tidak setuju 6 orang $(11 \%)$ dan responden yang menyatakan sangat tidak setuju 0 orang $(0 \%)$. Dari jawaban diatas, bahwa responden mayoritas menjawab sangat setuju yaitu sebanyak 24 orang (44\%).

Responden yang menyatakan sangat setuju bahwa saya menunjukkan suatu ide dan gagasan dalam menyelesaikan suatu persoalan sebanyak 7 orang (13\%), setuju 23 orang (42\%), kurang setuju 19 orang (32\%), tidak setuju 6 orang $(11 \%)$ dan responden yang menyatakan sangat tidak setuju 6 orang (11\%). Dari jawaban diatas, bahwa responden mayoritas menjawab setuju yaitu sebanyak 23 orang $(42 \%)$.

\section{Hasil Uji Validitas Dan Reliabilitas Secara Simultan}

Uji validitas digunakan untuk mengetahui apakah kuesioner yang disusun tersebut itu valid atau sahih, maka perlu diuji dengan uji korelasi antara skor (nilai) tiap-tiap item pernyataan dengan skor total kuesioner tersebut. Pada pengujian validitas dan reliabilitas peneliti mengambil 30 responden dari 55 jawaban responden dan pengolahan data dilakukan dengan menggunakan program SPSS versi 22.

Tabel 10 Validitas Jawaban Responden Secara Simultan

\begin{tabular}{|ll|r|r|}
\hline \multicolumn{3}{|c|}{ Case Processing Summary } \\
\hline Cases & Valid & N & \multicolumn{1}{c|}{$\%$} \\
\hline & Excluded & 100,0 \\
& 0 &, 0 \\
& Total & 30 & 100,0 \\
\hline
\end{tabular}


Volume 18 Nomor 2

\section{Sumber : Data diolah dengan SPSS}

Tabel 10 diatas, menunjukkan bahwa dari 30 jawaban responden 100\% sudah valid. Hasil uji reliabilitas secara simultan disajikan pada tabel berikut:

Tabel 11 Hasil Uji Reliabilitas Secara Simultan

Reliability Statistics

\begin{tabular}{|r|r|}
\hline Cronbach's Alpha & N of Items \\
\hline, 870 & 16 \\
\hline
\end{tabular}

Sumber : Data diolah dengan SPSS

Dari tabel diatas, diketahui bahwa ke-16 pernyataan dalam penelitian ini sudah reliabel, karena nilai cronbach's Alpha 0,870 >0,50. Selanjutnya, disajikan hasil uji validitas dan reliabilitas secara simultan berikut ini:

Tabel 12 Hasil Uji Validitas Dan Reliabilitas Secara Simultan Item-Total Statistics

\begin{tabular}{|l|r|r|r|r|}
\hline $\begin{array}{l}\text { Item } \mathbf{n}= \\
\mathbf{1 6}\end{array}$ & $\begin{array}{c}\text { Corrected Item-Total } \\
\text { Correlation }\end{array}$ & Keterangan & $\begin{array}{c}\text { Cronbach's Alpha if } \\
\text { Item Deleted }\end{array}$ & Keterangan \\
\hline SK1 &, 605 & Valid &, 858 & Reliabel \\
SK2 &, 436 & Valid &, 865 & Reliabel \\
SK3 &, 422 & Valid &, 866 & Reliabel \\
SK4 &, 383 & Valid &, 867 & Reliabel \\
SK5 &, 547 & Valid &, 860 & Reliabel \\
SK6 &, 483 & Valid &, 875 & Reliabel \\
K1 &, 698 & Valid &, 852 & Reliabel \\
K2 &, 461 & Valid &, 864 & Reliabel \\
K3 &, 561 & Valid &, 859 & Reliabel \\
K4 &, 591 & Valid &, 859 & Reliabel \\
K5 &, 601 & Valid &, 857 & Reliabel \\
PK1 &, 409 & Valid &, 867 & Reliabel \\
PK2 &, 593 & Valid &, 858 & Reliabel \\
PK3 &, 644 & Valid &, 857 & Reliabel \\
PK4 &, 404 & Valid &, 866 & Reliabel \\
PK5 &, 588 & Valid &, 858 & Reliabel \\
\hline
\end{tabular}

Sumber : Data diolah dengan SPSS

Dari tabel diatas, diketahui bahwa ke-16 pernyataan penelitian pada PT. Pelabuhan Indonesia I (Persero) Medan secara keseluruhan sudah valid, karena nilai $\mathrm{r}_{\text {hitung }}>0,30$. Dan seluruh variabel penelitian sudah reliabel, karena nilai cronbach's Alpha If item $>0,50$.

\section{E. Hasil Uji Validitas Dan Reliabilitas Secara Parsial}

Pengolahan data dilakukan dengan menggunakan program SPSS versi 22. Hasil uji validitas dan reliabilitas secara parsial pada variabel penelitian seleksi karyawan $\left(\mathrm{X}_{1}\right)$ disajikan pada tabel berikut:

Tabel 13 Validitas Jawaban Responden Untuk Variabel $X_{1}$

\begin{tabular}{|ll|r|r|}
\hline \multicolumn{3}{|c|}{ Case Processing Summary } \\
\hline Cases & Valid & \multicolumn{1}{c|}{$\%$} \\
& Excluded & \multicolumn{1}{c|}{100,0} \\
& 0 &, 0 \\
& Total & 30 & 100,0 \\
\hline
\end{tabular}


Volume 18 Nomor 2

\section{Sumber : Data diolah dengan SPSS}

Tabel diatas menunjukkan bahwa dari 30 jawaban reponden $100 \%$ sudah valid. Hasil uji reliabilitas secara parsial pada variabel disajikan seleksi karyawan pada tabel berikut:

Tabel 14 Hasil Uji Reliabilitas Untuk Variabel X (Seleksi Karyawan)

Reliability Statistics

\begin{tabular}{|r|r|}
\hline Cronbach's Alpha & N of Items \\
\hline, 715 & 6 \\
\hline
\end{tabular}

Sumber : Data diolah dengan SPSS

Pada tabel diatas, diketahui bahwa ke-6 pernyataan dalam penelitian ini sudah reliabel, karena Cronbach's Alpha 0,715 > 0,50. Selanjutnya disajikan hasil uji validitas dan reliabilitas secara parsial pada variabel seleksi karyawan berikut ini:

Tabel 15 Hasil Uji Validitas Dan Reliabilitas Untuk Variabel $\mathrm{X}_{1}$

Item-Total Statistics

\begin{tabular}{|l|rr|r|r|c|}
\hline Item n=6 & $\begin{array}{c}\text { Corrected Item-Total } \\
\text { Correlation }\end{array}$ & $\begin{array}{c}\text { Keterang } \\
\text { an }\end{array}$ & $\begin{array}{c}\text { Cronbach's Alpha if Item } \\
\text { Deleted }\end{array}$ & $\begin{array}{c}\text { Keterana } \\
\text { gn }\end{array}$ \\
\hline SK1 &, 410 & Valid & &, 687 & Reliabel \\
SK2 &, 324 & Valid &, 717 & Reliabel \\
SK3 &, 517 & Valid &, 653 & Reliabel \\
SK4 &, 494 & Valid &, 665 & Reliabel \\
SK5 &, 680 & Valid &, 599 & Reliabel \\
SK6 &, 393 & Valid & &, 720 & Reliabel \\
\hline
\end{tabular}

Sumber : Data diolah dengan SPSS

Dari tabel tersebut, diketahui bahwa ke-6 pernyataan penelitian pada PT. Pelabuhan Indonesia I (Persero) Medan secara keseluruhan sudah valid, karena nilai $r_{h i t u n g}>0,30$. Dan seluruh variabel penelitian sudah reliabel, karena nilai cronbach's Alpha If item > 0,50.

Hasil uji validitas secara parsial pada variabel komunikasi disajikan pada tabel berikut:

Tabel 16 Validitas Jawaban Responden Untuk Variabel $X_{2}$

Case Processing Summary

\begin{tabular}{|ll|r|r|}
\hline & \multicolumn{1}{|c|}{ N } & \multicolumn{1}{|c|}{$\%$} \\
\hline Cases & Valid & 30 & 100,0 \\
& Excluded $^{a}$ & 0 &, 0 \\
& Total & 30 & 100,0 \\
\hline
\end{tabular}

Sumber : Data diolah dengan SPSS

Berdasarkan Tabel diatas menunjukkan bahwa dari 30 jawaban reponden 100\% sudah valid. Hasil uji reliabilitas secara parsial pada variabel komunikasi disajikan pada tabel berikut:

Tabel 17 Hasil Uji Reliabilitas Untuk Variabel $X_{2}$ (Komunikasi)

Reliability Statistics

\begin{tabular}{|r|r|}
\hline Cronbach's Alpha & N of Items \\
\hline, 831 & 5 \\
\hline
\end{tabular}

Sumber : Data diolah dengan SPSS 
Pada tabel diatas, diketahui bahwa ke-5 pernyataan dalam penelitian ini sudah reliabel, karena Cronbach's Alpha 0,831 > 0,50. Selanjutnya disajikan hasil uji validitas dan reliabilitas secara parsial pada variabel komunikasi berikut ini:

Tabel 18 Hasil Uji Validitas Dan Reliabilitas Untuk Variabel $\mathrm{X}_{2}$ Item-Total Statistics

\begin{tabular}{|l|r|r|r|r|}
\hline $\begin{array}{l}\text { Item } \\
\mathbf{n = 5}\end{array}$ & $\begin{array}{c}\text { Corrected Item- } \\
\text { Total Correlation }\end{array}$ & Keterangan & \multicolumn{2}{|c|}{$\begin{array}{c}\text { Cronbach's Alpha if } \\
\text { Item Deleted }\end{array}$} \\
\hline K1 &, 645 & Valid &, 794 & Keterangan \\
K2 &, 407 & Valid &, 851 & Reliabel \\
K3 &, 725 & Valid &, 769 & Reliabel \\
K4 &, 632 & Valid &, 798 & Reliabel \\
K5 &, 756 & Valid &, 757 & Reliabel \\
\hline
\end{tabular}

Sumber : Data diolah dengan SPSS

Berdasarkan tabel diatas, diketahui bahwa ke-5 pernyataan penelitian pada PT. Pelabuhan Indonesia I (Persero) Medan secara keseluruhan sudah valid, karena nilai $\mathrm{r}_{\text {hitung }}>$ 0,30. Dan seluruh variabel penelitian sudah reliabel, karena nilai cronbach's Alpha If item $>0,50$.

Hasil uji validitas secara parsial pada variabel prestasi kerja karyawan (Y) disajikan pada tabel berikut:

Tabel 19 Validitas Jawaban Responden Untuk Var
\begin{tabular}{|ll|r|r|}
\hline \multicolumn{3}{|c|}{ Case Processing Summary } \\
\hline Cases & Valid & N & \multicolumn{1}{c|}{$\%$} \\
\hline & Excluded & 30 & 100,0 \\
& Total & 30 & 100,0 \\
\hline
\end{tabular}

Sumber : Data diolah dengan SPSS

Tabel diatas menunjukkan bahwa dari 30 jawaban reponden $100 \%$ sudah valid. Hasil uji reliabilitas secara parsial pada variabel prestasi kerja karyawan disajikan pada tabel berikut:

Tabel 20 Hasil Uji Reliabilitas Untuk Variabel Y (Prestasi Kerja Karyawan)

Reliability Statistics

\begin{tabular}{|r|r|}
\hline Cronbach's Alpha & N of Items \\
\hline, 668 & 5 \\
\hline
\end{tabular}

Sumber : Data diolah dengan SPSS

Pada tabel diatas, diketahui bahwa ke-5 pernyataan dalam penelitian ini sudah reliabel, karena Cronbach's Alpha 0,668 > 0,50. Selanjutnya disajikan hasil uji validitas dan reliabilitas secara parsial pada variabel prestasi kerja karyawan berikut ini:

Tabel 21 Hasil Uji Validitas Dan Reliabilitas Untuk Variabel Y Item-Total Statistics

\begin{tabular}{|c|c|c|c|c|}
\hline Item $n=$ & $\begin{array}{c}\text { Corrected Item-Total } \\
\text { Correlation }\end{array}$ & Keterangan & $\begin{array}{c}\text { Cronbach's Alpha if Item } \\
\text { Deleted }\end{array}$ & $\begin{array}{c}\text { Keterang } \\
\text { an }\end{array}$ \\
\hline PK1 & ,393 & Valid & 637 & Reliabel \\
\hline PK2 & 382 & Valid & 633 & Reliabel \\
\hline PK3 & ,527 & Valid & ,575 & Reliabel \\
\hline PK4 & ,484 & Valid & 675 & Reliabel \\
\hline PK5 & 558 & Valid & 552 & Reliabel \\
\hline
\end{tabular}


Volume 18 Nomor 2

Sumber : Data diolah dengan SPSS

Dari tabel tersebut, diketahui bahwa ke-5 pernyataan penelitian pada PT. Pelabuhan Indonesia I (Persero) Medan secara keseluruhan sudah valid, karena nilai $r_{\text {hitung }}>0,30$. Dan seluruh variabel penelitian sudah reliabel, karena nilai cronbach's Alpha If item $>0,50$.

\section{F. Uji Simultan (Uji F)}

Uji simultan dilakukan untuk menunjukkan bahwa secara simultan terdapat pengaruh antara variabel bebas yaitu seleksi karyawan dan komunikasi terhadap variabel terikat yaitu prestasi kerja karyawan. Hal ini dapat dilihat dengan membandingkan $\mathrm{F}_{\text {hitung }}$ dan $\mathrm{F}_{\text {tabel }}$ pada tingkat signifikansi $(\alpha)=5 \%$.

Tabel 22 Rekapitulasi Hasil Perhitungan Pengaruh Seleksi Karyawan dan Komunikasi Terhadap Prestasi Kerja Karyawan secara simultan

ANOVA $^{a}$

\begin{tabular}{|c|c|c|c|c|c|}
\hline Model & Sum of Squares & Df & Mean Square & $\mathbf{F}$ & Sig. \\
\hline Regression & 255,444 & 2 & 127,722 & 31,283 &, $000^{\mathrm{b}}$ \\
\hline Residual & 212,302 & 52 & 4,083 & & \\
\hline Total & 467,745 & 54 & & & \\
\hline
\end{tabular}

Sumber : Data diolah SPSS

Berdasarkan tabel diatas, menunjukkan bahwa terdapat pengaruh positif dan signifikan antara variabel bebas (seleksi karyawan dan komunikasi terhadap prestasi kerja karyawan). Pengaruh tersebut ditunjukkan pada nilai $\mathrm{F}_{\text {hitung }}$ sebesar 31,283 $>\mathrm{F}_{\text {tabel }}$ sebesar 3,18 dan tingkat signifikansi $0,000<0,05$ sehingga dapat disimpulkan bahwa secara simultan variabel seleksi karyawan dan komunikasi mempengaruhi prestasi kerja karyawan pada PT. Pelabuhan Indonesia I (Persero) Medan.

\section{G. Uji Parsial (Uji t)}

Uji parsial dilakukan untuk mengetahui pengaruh secara parsial antara variabel bebas terhadap variabel terikat, besarnya pengaruh tersebut dapat dilihat pada tabel berikut.

Tabel 23 Rekapitulasi Hasil Perhitungan Pengaruh Seleksi Karyawan dan Komunikasi

Terhadap Prestasi Kerja Karyawan Secara Parsial.

Coefficients $^{a}$

\begin{tabular}{|c|c|c|c|c|c|}
\hline \multirow[b]{2}{*}{ Model } & \multicolumn{2}{|c|}{$\begin{array}{l}\text { Unstandardized } \\
\text { Coefficients }\end{array}$} & \multirow{2}{*}{$\begin{array}{c}\begin{array}{c}\text { Standardized } \\
\text { Coefficients }\end{array} \\
\text { Beta }\end{array}$} & \multirow[b]{2}{*}{$T$} & \multirow[b]{2}{*}{ Sig. } \\
\hline & B & Std. Error & & & \\
\hline (Constant) & 6,222 & 1,601 & & 3,887 & ,000 \\
\hline SK & 256 & ,083 & 33 & 3,091 & ,003 \\
\hline $\mathrm{K}$ & ,401 & ,085 & ,5] & 4,702 & ,000 \\
\hline
\end{tabular}

Sumber: Data diolah dari SPSS

Dari tabel diatas dengan $a=5 \%$ dan uji satu arah diketahui bahwa nilai $t_{\text {tabel }}$ sebesar 1,674 dengan ketentuan $t_{\text {hitung }}>t_{\text {tabel }}$ dan untuk menentukan signifikansi variabel bebas dengan variabel terikat maka dilihat dari nilai signifikan harus lebih kecil dari a $=5 \%$. Maka dari tabel dapat diketahui bahwa, nilai uji thitung untuk variabel seleksi karyawan sebesar 3,091 > 1,674 dan tingkat signifikan sebesar $0,003<0,05$ sehingga $\mathrm{H}_{1}$ diterima dan $\mathrm{H}_{0}$ ditolak. Artinya, seleksi karyawan berpengaruh positif dan signifikan terhadap prestasi kerja karyawan. 
Nilai uji thitung untuk variabel komunikasi sebesar 4,702 > 1,674 dan tingkat signifikan $0.000<0,05$ sehingga $\mathrm{H}_{1}$ diterima dan $\mathrm{H}_{0}$ ditolak. Artinya, komunikasi berpengaruh positif dan signifikan terhadap prestasi kerja karyawan.

\section{H. Pengujian Determinasi $\left(R^{2}\right)$}

Koefisien korelasi (R) berguna untuk mengetahui variasi antara seleksi karyawan dan komunikasi terhadap prestasi kerja karyawan pada PT. Pelabuhan Indonesia I (Persero) I Medan. Koefisien determinan ( $R$ Square) berguna untuk mengetahui sejauh mana variasi variabel prestasi kerja karyawan dapat dijelaskan oleh variabel seleksi karyawan dan komunikasi. Berdasarkan print output SPSS versi 22 diperoleh sebagai berikut:

Tabel 24 Model Summary

Model Summary

\begin{tabular}{|l|r|r|r|r|}
\hline Model & \multicolumn{1}{|c|}{ R } & R Square & Adjusted R Square & Std. Error of the Estimate \\
\hline 1 &, $739 \mathrm{a}$ &, 546 &, 529 & 2,021 \\
\hline
\end{tabular}

Sumber : Data diolah dengan SPSS

Berdasarkan tabel diatas, terlihat bahwa:

1. Nilai $R$ sebesar 0,739 sama dengan $73,9 \%$ berarti hubungan antara variabel seleksi karyawan $\left(\mathrm{X}_{1}\right)$ dan komunikasi $\left(\mathrm{X}_{2}\right)$ terhadap variabel prestasi kerja karyawan $(\mathrm{Y})$ sebesar $73,9 \%$ atau berhubungan erat.

2. Koefisien determinasi (R Square) adalah sebesar 0,546 artinya $54,6 \%$ bahwa prestasi kerja karyawan dapat dijelaskan oleh seleksi karyawan dan komunikasi, dan sisanya 45,4\% dijelaskan oleh variabel lain yang tidak termasuk dalam penelitian ini.

3. Standard Error pf the Estimate (SEE) artinya mengukur akurasi dari nilai yang diprediksi. Nilai SEE 2,021, semakin mendekati angka nol (0) maka semakin akurat pengaruhnya.

I. Pengaruh Seleksi Karyawan Terhadap Prestasi Kerja Karyawan Pada PT. Pelabuhan Indonesia I (Persero) Medan

Hasil penelitian menunjukkan bahwa variabel seleksi karyawan berpengaruh positif dan signifikan terhadap prestasi kerja karyawan pada PT. Pelabuhan Indonesia I (Persero) Medan. Hal ini dibuktikan dengan nilai koefisien regresi sebesar 0,256. Artinya jika seleksi karyawan yang diterapkan oleh PT. Pelabuhan Indonesia I (Persero) Medan naik 1 poin maka prestasi kerja karyawan akan meningkat sebesar 0,256. Berdasarkan uji parsial (uji t) untuk variabel seleksi karyawan diperoleh nilai $t_{\text {hitung }}(3,091)>t_{\text {tabel }}(1,674)$ dan tingkat signifikansinya $0,003<$ 0,05 sehingga $\mathrm{H}_{0}$ ditolak dan $\mathrm{H}_{1}$ diterima. Dengan ditolaknya $\mathrm{H}_{0}$ berarti seleksi karyawan berpengaruh positif dan signifikan terhadap prestasi kerja karyawan pada PT. Pelabuhan Indonesia I (Persero) Medan. Dengan demikian indikator dalam variabel seleksi karyawan perlu dipelihara dan ditingkatkan karena dapat meningkatkan prestasi kerja karyawan.

\section{J. Pengaruh Komunikasi Terhadap Prestasi Kerja Karyawan Pada PT. Pelabuhan Indonesia I (Persero) Medan}

Hasil penelitian menunjukkan bahwa variabel komunikasi berpengaruh positif dan signifikan terhadap prestasi kerja karyawan pada PT. Pelabuhan Indonesia I (Persero) Medan. Hal ini dibuktikan dengan nilai koefisien regresi sebesar 0,401. Artinya jika sebesar 0,401 hal ini ditunjukkan nilai koefisien regresinya. Artinya jika komunikasi yang diterapkan oleh PT. Pelabuhan Indonesia I (Persero) Medan naik 1 poin maka pestasi kerja karyawan akan meningkat sebesar 0,401. Berdasarkan uji parsial (uji t) untuk variabel komunikasi diperoleh nilai $t_{\text {hitung }}(4,702)>t_{\text {tabel }}(1,674)$ dan tingkat signifikansinya $0,000<0,05$ sehingga $\mathrm{H}_{0}$ ditolak dan $\mathrm{H}_{1}$ diterima. Dengan ditolaknya $\mathrm{H}_{0}$ berarti komunikasi berpengaruh positif dan signifikan 
terhadap prestasi kerja karyawan pada PT. Pelabuhan Indonesia I (Persero) Medan. Dengan demikian indikator dalam variabel komunikasi perlu dipelihara dan ditingkatkan karena dapat meningkatkan prestasi kerja karyawan.

\section{KESIMPULAN}

Berdasarkan hasil pembahasan, dapat disimpulkan bahwa:

1. Seleksi karyawan berpengaruh positif dan signifikan terhadap prestasi kerja karyawan pada PT. Pelabuhan Indonesia I (Persero) Medan. Dilihat dari koefisien regresinya diketahui bahwa $t_{\text {hitung }}$ untuk variabel seleksi karyawan adalah 3,091 sedangkan nilai $t_{\text {tabel }}$ 1,674 sehingga 3,091 $>1,674$. Selain itu untuk nilai signifikansinya $(0,003<0,05)$ dengan memperhatikan nilai $t_{\text {tabel }}$ (uji satu arah) maka $\mathrm{H}_{1}$ diterima dan $\mathrm{H}_{0}$ ditolak.

2. Komunikasi berpengaruh positif dan signifikan terhadap prestasi kerja karyawan pada PT. Pelabuhan Indonesia I (Persero) Medan. Dilihat dari koefisien regresinya diketahui bahwa $t_{\text {hitung }} 4,702>t_{\text {tabel }} 1,674$ dan nilai signifikan $(0,000<0,05)$ sehingga $H_{1}$ diterima dan $\mathrm{H}_{0}$ ditolak.

3. Seleksi karyawan dan komunikasi berpengaruh positif dan signifikan secara simultan terhadap prestasi kerja karyawan pada PT. Pelabuhan indonesia I (Persero) Medan. Hal ini dapat dilihat dari uji $\mathrm{F}_{\text {hitung }}>\mathrm{F}_{\text {tabel }}$ adalah sebesar 31,283 $>3,18$ dengan tingkat signifikan $0,000<0,05$ maka $\mathrm{H}_{1}$ diterima dan $\mathrm{H}_{0}$ ditolak. Dengan persamaan regresi linier berganda adalah $\mathrm{Y}=6,222+0,256 \mathrm{SK}+0,401 \mathrm{~K}+$ ei.

4. Koefisien determinasi sebesar 0,546 atau $54,6 \%$ menjelaskan bahwa variabel prestasi kerja karyawan (Y) mampu dijelaskan oleh variasi variabel seleksi karyawan $\left(\mathrm{X}_{1}\right)$ dan komunikasi $\left(\mathrm{X}_{2}\right)$ sebesar $54,6 \%$ dan sisanya $45,4 \%$ dijelaskan oleh variabel yang tidak diteliti dalam penelitian ini seperti disiplin kerja, motivasi, gaya kepemimpinan, budaya organisasi dan faktor lainnya.

\section{DAFTAR PUSTAKA}

Anthoillah, Anton.2010. Dasar-dasar Manajemen. C.V Pustaka Setia : Bandung.

Ambar Teguh. 2009. Manajemen Sumber Daya Manusia. Graha ilmu : Jakarta.

Edy Sutrisno.2013. Manajemen Sumber Daya Manusia. PT. Kencana Prenada Media Group : Jakarta.

Ghozali, Imam. 2006. Aplikasi Analisis Multivariate dengan Program SPSS. Semarang : Badan Penerbit Universitas Diponegoro.

Gibson,James. 2012. Organization Behavior Structure Processes. Eight Edition : Boston.

Haryani. 2010. Jurnal Manajemen dan Kewirausahaan, Hal 40-45

Handoko, T.H. 2001. Manajemen Personalia dan sumber Daya manusia. Yogyakarta : BPFE.

Hasibuan, Malayu. 2008. Manajemen Sumber Daya Manusia, Edisi Revisi, Cetakan Ketujuh,

Penerbit : Bumi Aksara, Jakarta.

Irianto, Yusuf. 2001. Pengantar Manajemen. Yogyakarta : Graha Ilmu.

Khaerul Umam. 2010. Perilaku Organisasi. Pustaka setia : Bandung.

Luthan, Fred. 2011. Organizational Behavior. Twelfth Edition. NY : McGraw-Hill/Irwin.

Mangkunegara, A.P. 2000. Manajemen Sumber Daya Manusia. Bandung : PT. Remaja Rosda Karya.

2013. Manajemen Sumber daya Manusia. Bandung : PT. Remaja Rosda Karya.

Moenir dalam Sjafri Mangkuprawira. 2003. Manajemen Sumber Daya Manusia Strategik. Jakarta

: Ghalia Indonesia.

Newstrom, John W. \& Keith Davis. 2004. Perilaku dalam Organisasi. Jakarta : Erlangga.

Purwanto, Djoko. Drs. MBA. 2006. Komunikasi Bisnis. Edisi Ketiga, Jakarta : Erlangga.

Rivai, Veitzhal. 2008. Manajemen Sumber Daya manusia Untuk Perusahaan: dari Teori ke Praktik, Jakarta:Raja Grafindo Persada. 
Robbins, Timothy A. Judge dalam Wibowo. 2013. Perilaku Organisasi. Jakarta : Penerbit Salemba Empat.

Simamora, Hendry. 2004. Manajemen Sumber Daya Manusia. STIE. YKPN: Yogyakarta.

Siswanto, Bejo. 1989. Manajemen Tenaga Kerja. Sinar Baru. Bandung.

Supardi, Anwar Syaiful. 2002. Dasar-dasar Perilaku Organisasi. UII Press : Yogyakarta.

Sjafri Mangkuprawira. 2003. Manajemen Sumber Daya Manusia Strategik. Jakarta : Graha indonesia.

Sugiyono.2008. Metode Penelitian Kualitatif dan R E P. Bandung: Alfabeta.

Sunyoto, Agus. 2008. Manajemen Sumber Daya Manusia. Edisi Revisi. Perpustakaan Nasional : Penerbit IN MEDIA.

Yuli.2005. Manajemen Sumber Daya Manusia. Malang : UMM Press.

Yuliarsih Tjuju, Suwatno.2008. Manajemen Sumber Daya Manusia. Jakarta : PT. Bumi Askara.

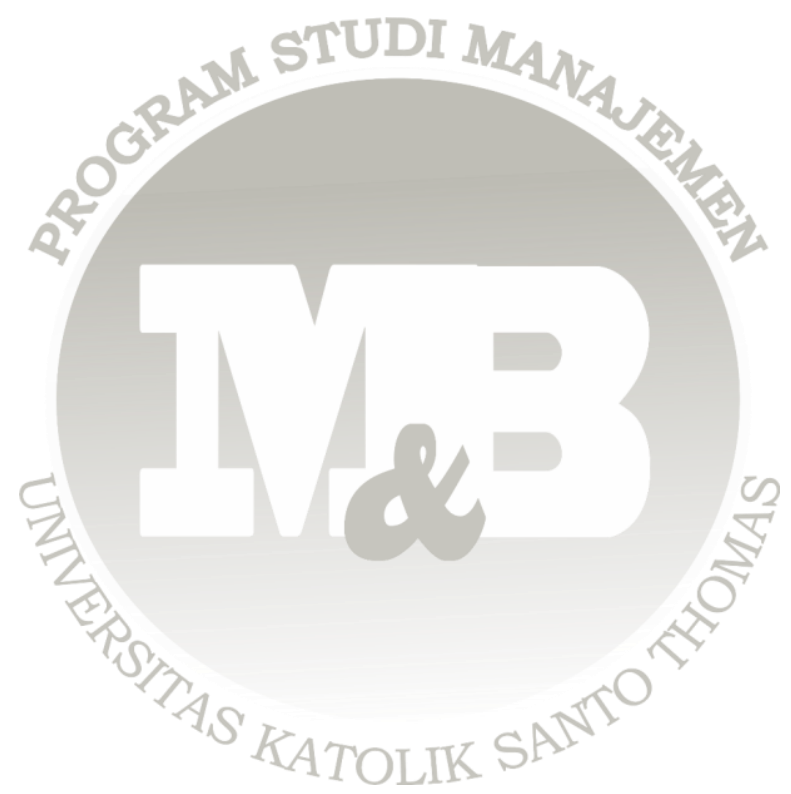

